\title{
Evangelical Zionism in Jerusalem
}

"The Embassy" - shorthand for the International Christian Embassy Jerusalem in Evangelical parlance-is situated on Rachel Imeinu Street in what is known as the German Colony: a lush and slower-paced neighborhood in the western part of the city, away from Jerusalem's immediate center. It is a pleasant part of town, sprinkled with small boutiques, Italian cafés, bars, and some residencies of ambassadors and diplomats. Previously the area also housed several of the national embassies that have been relocated to Tel Aviv as a result of the passing of the Jerusalem Law and the subsequent international protests against it in 1980. The German Colony has an interesting history. More than hundred years ago, it was established by a group of Pietist settlers called "the Templers" which was led by the German theologian and politician, Christoph Hoffman. Like several other Christian groups that set up in Palestine during the course of the nineteenth and early-twentieth centuries the Templers were inspired by millennial ideas. In this particular case, that spiritual cooperation, cultivation of the land, and rebuilding the temple would mark the beginning of the kingdom of God and the millennial era. In the 1940s the seven colonies that the Templers had established in the second half of the twentieth century, including the one in Jerusalem, were dismantled by the British, and any remaining Templers were deported to Austria and Australia, never to return (Kroyanker 2008).

In what looks like a happy coincidence, the side-streets of the German Colony today are named for famous Gentile supporters of Zionism such as former British Prime Minister, David Lloyd George, the French Nobel Prize winner, Emile Zola, and the South African politician, Jan Smuts. The street where the ICEJ is located, however, has a more biblical ring to it: "Rachel, our mother". The large and beautiful mansion that houses the Embassy also has a fascinating history; built in the middle of the mandate period by the Christian Arab contractor Ibrahim Haki, it hosted several embassies and consulates before the ICEJ took up residence there in 1997. Previously the ICEJ had rented several other buildings, among them the house on Brenner Street which post-colonial theorist Edward Said claimed to have been his childhood home before his family was evicted as part of the 1948 struggles: a story which has frequently been picked up in literature about the ICEJ. In a 1992 article, and a later BBC documentary, Said showed his audience the building, and described how it was now occupied by a "right-wing 
fundamentalist Christian and militantly pro-Zionist group, run by a South African Boer no less!" (Said 1992) ${ }^{1}$ Said's claim to have lived in the house was later questioned in a series of critical articles by Justin Wiener from the Jerusalem Center for Public Affairs (e.g. 1999)—no doubt with his own political agenda; the claim is also contested by ICEJ staff when queried on the issue. Whatever the truth of it is, the story about the takeover of Said's childhood home by the "South African Boer" has come to symbolize the colonialism of the Christian Zionist enterprise in literature critical of the ICEJ: the unequal power dynamics, the militant fundamentalism, the arrogance of Western Christians, and their indifference towards indigenous voices (Cohn-Sherbok 2006, 167, Halsell 2003, 91, Wagner 1995, 97). As a story it is, perhaps, too good not to be true.

In a sense, the ICEJ seems perfectly placed, given the history of the German Colony with its millennialist settlers, the streets named after gentile supporters, and the diplomatic air of the ambassadorial surroundings. It is almost as if the move away from Brenner Street-with all its symbolical implications of militancy, fundamentalism, and colonialism - to the house on Rachel Imeinu Street signifies the deeper theological and ideological transformation that the ICEJ has aimed to accomplish in the last fifteen years: a transformation which, in their view, is a move away from flamboyant apocalypticism and high-profile political radicalism towards lower-key considerations of God's covenantal promises to the Jews and a more solid and respectable role in Israeli society. The shift from Brenner Street is one in social space as much as in geography: it represents respectability and social status, and a proper standing as an embassy symbolically representing the Kingdom of God vis à vis Israeli society and the Jewish people. This transformation is far from complete, however, and much of their social and linguistic practice is the result of balancing these desires between biblically grounded eternal truths and the pragmatism necessary to function, as it were, "diplomatically" (McConnell, Moreau, and Dittmer 2012) on intense discursive terrain.

\section{History of the Organizations}

At least since the decades following the Protestant reformation, ideas about a future Jewish national restoration have been an important theological

1 The "South African Boer" mentioned by Said was Johann Lückhoff who was the executive director of the ICEJ from when it was founded in 1980 until 2000 when he was replaced by another South African, Malcolm Hedding. 
undercurrent in various Protestant movements. During the sixteenth century, several Protestant thinkers including Henoch Clapham, Thomas Brightman, and Joseph Mede speculated about the Jewish historical destiny, and during the seventeenth century such ideas flourished both in Puritan England (Lewis 2010, Smith 2013) and in northern European Pietist milieus (Ariel 2014, Stewart 2015). As noted in Chapter One, scholars focusing on the North American context have often paid particular attention to theological developments in the British Isles. Historian Robert O. Smith, for instance, has argued that the sources for "contemporary American affinity for the State of Israel" are primarily found within a tradition of "Judeo-centric prophecy interpretation" (Smith 2013, 3) first developed by Protestant theologians in the early Elizabethan period, refined in the seventeenth century, brought to North American via the Puritan settlers, and later adopted into the emerging fundamentalist culture (185).

In the late 1800 s several Christian Restorationists were also actively involved in political work on behalf of the emerging Zionist movement. In North America, William E. Blackstone wrote a petition to President Benjamin Harris in 1891 in order to convince him to help set up a Jewish-administered state in Palestine. Twenty-five years later, he repeated the request in another petition to President Woodrow Wilson (Smith 2013, 167-168, Boyer 1992). On the European continent, the Rev. William Hechler was another politically active Christian who worked with Zionist leaders such as Theodore Herzl and Leon Pinsker in order to set up a Jewish nation in Palestine (Goldman 2009). Similarly, the Protestant Restorationist influence on the Balfour declaration in 1917, primarily exercised through the Earl of Shaftesbury, has also been frequently described in previous literature (Lewis 2010, Smith 2013, Tuchman 1983).

Since much of this history of "Judeo-centric prophecy belief", along with the various Protestant programs to further Jewish settlement in Palestine, has been discussed in detail elsewhere, I will not reiterate that here. My focus, rather, lies on how the Christian ministries in Jerusalem have engaged with this history in terms of their self-understanding, and the ways in which they have developed in relation to Israeli society over the past forty years. Although frequently discussed in the media, an exhaustive scholarly account of the organizations' history has yet to be produced. The publications that have addressed them at any length have also tended to treat them as largely stable over time. While critical accounts, such as Ariel's (1997), locates the ICEJ in relation to "fundamentalism" and "dispensationalism", more sympathetic accounts such as those by Paul Merkley (2001) and Faydra L. Shapiro (2015) tend to emphasize contemporary formulations as also representative of the organizations 
historically. ${ }^{2}$ Although I draw on all these accounts here I try to complement them by tracing the organizations' historical development in relation to the society in which they operate. After briefly discussing the question of premillennial dispensationalism - due to its importance in considerable scholarly work on Christian Zionism and the ministries in Jerusalem-I turn to the development of the ministries starting with the prophetic excitement that followed the Israeli victory in the Six-Day War in June 1967.

\section{Restorationism and Dispensationalism}

While Judeo-centric prophecy belief, sometimes with Restorationist aims and activities, has flourished in several different Protestant contexts historically, one such tradition - that of premillennial dispensationalism-has received the bulk of attention and often been understood as the main historical source for contemporary Christian Zionism (e.g. Spector 2009, Weber 2004). Dispensationalism is an elaborate eschatological system developed in the midnineteenth century by John Nelson Darby of the Plymouth Brethren. Darby's system divides history, as well as the biblical text, into distinct eras which structure the ways in which God deals with humanity. Darby also separated the two peoples of God—-the Jewish people and the Church — and argued that particular biblical prophecies only referred to the former. The most distinctive tenet of dispensationalism can be said to be the rapture of the church which marks the end the present era and restarts God's timetable. ${ }^{3}$ Thus, for

2 It should be noted that Paul Merkley, apart from being a historian, is also a long-term member of the ICEJ's international board, and thus generally sympathetic to their views. His portrayal of the ICEJ and similar organizations demonstrates an unwillingness to engage in any critical analysis of their ideas or practices while his analysis of "Christian anti-Zionist" voices is shallow, polemical, and generally misleading (Merkley 2001).

3 The biblical basis of the doctrine of the rapture is primarily found in 1 Thess. 4:17: "Then we who are alive, who are left, will be caught up in the clouds together with them to meet the Lord in the air; and so we will be with the Lord forever". Among premillennialist Christians this passage in conjunction with other eschatological passages of the Bible has been understood as a prophecy concerning the "hidden return" of Christ which is expected to occur prior to the tribulation. "Caught up" (lat. raptus) is a supernatural event in which believing Christians are physically brought up to God and saved from the horrors of the apocalypse. While the rapture has been a part of Bible prophecy circles for the past two centuries, more recently the doctrine has undergone a remarkable popularization by being included in Christian cultural products such as the 1972 movie $A$ Thief in the Night, The Late Great Planet Earth (novel), the Left Behind series (novels and films), and online communities such as Rapture Ready. Even more recently the idea has also been explored in non-Christian products such as the novel and TV-series The Leftovers and the computer game Everybody's Gone to the Rapture. For more on how the Rapture functions as a cultural product see (Howard 2011, Johnson Frykholm 2004). 
Darby, no prophetic fulfillment would happen until after the "any-momentnow" rapture. None of these features however, was unique to Darby's system; they had existed in various formulations before him and continued to do so after the emergence of dispensationalism and its adaptation by North American Evangelicalism in the early 19oos. Dispensationalism became influential in the emerging fundamentalist milieu, while, particularly as the result of the acceptance of Darby's ideas by revivalist preachers such as William E. Blackstone, Dwight L. Moody, and Cyrus I. Scofield, the system also underwent a series of transformations in the North American context.

In relation to the Evangelical ministries in Jerusalem there are two important things to note about dispensationalism. Firstly, as several observers have argued, the association between the ministries and premillennialism has been vastly overstated in much previous research (Shapiro 2015, Westbrook 2014). Dispensationalism is no longer a particularly common self-identity among Evangelical Zionists and only a clear minority would be able to explain the dispensational system in any detail. During my time in Jerusalem, I only met one volunteer who self-consciously identified himself as dispensationalist, but even in his case it was with dispensationalism in one of its later forms (Ryrie 1995). Christian Zionists in general and the ICEJ in particular, also prefer to see themselves not as a modern application of dispensationalism but rather as heirs of a long history of Protestant Judeo-centric restorationism. In the case of the ICEJ, this identity is sometimes even phrased in explicit contrast to premillennial dispensationalism.

Flowing from all these biblical truths [Rom. 11], the ICEJ simply cannot endorse dispensationalist teachings, such as different ways of salvation in preceding ages, that the Church was an after-thought of God following the Jewish rejection of Jesus, or that it is a "parenthesis" in time. For this and other reasons, it is erroneous and misleading for anyone to associate us with Dispensationalist thinking.

PARSONS 2013, $28^{4}$

In contrast to, and critique of, Timothy Weber's narrative that places the ICEJ as a direct consequence of North American dispensationalism (Weber 2004), David Parsons, the media director of the ICEJ, argues that the "true and noble origins of Christian Zionism" should be traced instead to the "very infancy of

4 Parsons' article Swords into Ploughshares: Christian Zionism and the Battle of Armageddon is not officially published but is freely available at the ICEJ website. I received the text in its final form in 2013 from David Parsons. 
the Protestant reformation" $(2013,6)$. Their "theology, actions and motives", he writes,

are based on biblical principles and promises, which are backed up by biblical prophecies and New Testament truths. Our position is best identified as Biblical Zionism, which rests on Covenantal Theology. Our approach ... views both the Jewish people and Land of Israel as chosen by God long ago for purposes of world redemption. Thus we have the interest and fate of the entire world in heart and mind when we defend Israel's restoration to her land.

PARSONS 2O13, 2-3

This identification with broader restorationist traditions has in the ICEJ's case been explicit since the "first Christian Zionist Congress" in Basel 1985 in which the ICEJ consciously identified themselves as the heirs of European restorationism, particularly the work of William Hechler (Ariel 1997). ${ }^{5}$

Secondly, while dispensationalism as an elaborated theological system is not very popular amongst contemporary Evangelical Zionists in Jerusalem for a variety of reasons, it is still necessary to recognize the influence dispensationalism as a popular theology has had in spreading Christian Zionist ideas and the identifications between the Zionist movement and Christian sacred history. Classic dispensationalism was strictly futurist and advocated a separatist anti-political approach to society (Smith 2013). Such ideas are not only out of fame but even antithetical to contemporary Christian Zionism (Westbrook 2010). Yet dispensationalism had a profound influence on the emerging fundamentalist movement in North America, and underwent a series of modifications that made it able to account for the Jewish national restoration as fulfillment of prophecy, particularly through the work of William E. Blackstone (Smith 2013). With the influence of the Scofield Reference Bible, popular dispensationalism also became identified with the cause of Evangelical Biblicism in opposition to liberal or modernist theologies. ${ }^{6}$ Moreover, in its

5 "International Christian Zionist Congress, Basel, 27.-29. August 1985", Central Zionist Archives, $\left.\mathrm{A}_{15}\right|_{15} 82$, Jerusalem.

6 The Scofield Reference Bible was widely influential in the spread of dispensationalist ideas. Historian Paul Boyer has made the important observation that "unlike most commentators Scofield combined his notes and the biblical text on the same page, so the former took on much the same authority as the latter" $(1992,98)$. This is a significant point; by Scofield's juxtaposition of the biblical text and his own dispensationalist commentaries an identification was made between the two that helped further the latter as "biblical", indeed, even as "literal". "Readers," according to Boyer, "often could not remember whether they had encountered a particular thought in the notes or in the [biblical] text" $(1992,98)$. 
modified forms dispensationalism came to significantly contribute to the development of prophecy fiction in the style of Hal Lindsey and Carol C. Carlson's The Late Great Planet Earth as well as Tim LaHaye's and Jerry B. Jenkins Left Behind series. Such works embedded a modified dispensationalism in the culture of Evangelical Biblicism and contributed to the spread of ideas about the Jewish national restoration as a fulfillment of prophecy. Consequently, the popularization that dispensationalism underwent in the North American context, primarily during a few decades in the mid-19oos, did much to establish the identifications between Zionism, Bible prophecy, and biblical literalism. As such, fictional prophecy works and other cultural products that draw on these ideas are part of the "textual economies" (Bielo 2009, 110) by which Evangelicals make sense of the State of Israel and Zionism.

Thus, in the context of contemporary Jerusalem, I share Faydra L. Shapiro's general observation that the "connection between premillennial dispensationalism and Christian Zionism has been vastly overdrawn" (2015), and that it is reasonable to approach the organizations primarily through their self-understanding as embodying a modern application of Protestant restorationism. Yet it is crucial that these contemporary expressions of the organizations' guiding theology are also contextualized historically and discursively. Taking them too much at face value - as Shapiro often does in spite of her insistence that the boundaries of religions are ideological products_-risks naturalizing these claims as transparent reflections of inner motives and makes the historical trajectories by which they have developed invisible. The organizations' insistence that they are based on eternal and unchanging "biblical mandates" leave them little room to consider their own ideological development over time, but that does not mean that there have been no such developments. As I hope to show below, these developments need to be understood in relation to the organizations' quest for legitimacy in Israeli society and their broader ideological aims.

\section{Jerusalem in the $1970 \mathrm{~s}$}

Robert O. Smith writes that for early-twentieth century Christian Zionists who long had imagined a future Jewish restoration, the Balfour Declaration of $1917,{ }^{7}$

7 "The Balfour Declaration" was issued on November 21917 and stated that "His Majesty's government view with favour the establishment in Palestine of a national home for the Jewish people, and will use their best endeavours to facilitate the achievement of this object, it being clearly understood that nothing shall be done which may prejudice the civil and religious rights of existing non-Jewish communities in Palestine, or the rights and political status enjoyed by Jews in any other country". Originally it was written by UK's foreign secretary Arthur James Balfour to Walter Rothschild, later it was included in official British policy towards Palestine. 
the founding of the State of Israel in 1948, and its territorial expansion in 1967 came as a validation of "theological commitments centuries in the making." $(2013,193)$. Even before the founding of the state, however, the British mandate had attracted many different varieties of millennial groups, Christian missionaries of both conservative and liberal orientations, and Protestant travelers who were fascinated with the achievements of the Zionist movement and often identified them with biblical prophecies (Goldman 20o9, Newberg 2012, Stewart 2015, van Oord 2008). Outside Israel's borders Christians were also largely positive in their attitudes to the new state, some on eschatological grounds, other more for humanitarian or political reasons (Carenen 2012). The Six-Day War in 1967 in which Israel conquered the Golan heights, the Sinai peninsula, the Gaza Strip, and the West Bank including East Jerusalem, however, would prove a major turning point in Protestant-Israel relations (Boyer 1992, Carenen 2012, Weber 2004).

The Israeli authors Idith Zertal and Akiva Eldar have described the period that followed upon the Israeli victory in ' 67 as one of "Messianic zeal": a sense of euphoria in which everything suddenly seemed possible. For the first time in two millennia the Jewish people controlled the larger Land of Israel including the West Bank and East Jerusalem. The beginnings of the settlement enterprise, and the emergence of the national religious camp in the public arena, is understood by Zertal and Eldar in relation to this broader messianic excitement that characterized the years following June '67 (2007, also Ravitsky 1996). On the other hand, Caitlin Carenen describes how the Israeli victory was met with ambivalent responses from mainline Christians in North America, most of whom had been positive towards Israel until then. While some prominent theologians including Reinhold Neibuhr, Martin Luther King Jr., and Krister Stendahl signed a statement in support of Israel's recent acquisition of Jerusalem, others expressed concern over Israeli expansionism and the deteriorating humanitarian situation for the Palestinians. The North American National Council of Churches, for instance, declared that it could not "condone by silence territorial expansion by armed force" (Merkley 2001). In time, the latter position would grow in prominence among liberal and mainline Christians in the US and elsewhere (Carenen 2012, 137-140), and is apparent, for instance, in the development of the World Council of Churches' perspective on the Israeli-Palestinian conflict (Ekin 1985).

But if liberal Christians were ambivalent towards Israel after ' 67 , Evangelicals were far more enthusiastic and generally understood the Israeli victory in terms of prophetic fulfillment. To describe the experience of peoples or groups that have entered the apocalypse phenomenologically, historian Richard Landes has coined the term "semiotically aroused", by which he means state of mind where 
everything quickens, enlivens, coheres ... everything has meaning, patterns. The smallest incident can have immense importance and open the way to an entirely new vision of the world, one in which forces unseen by other mortals operate.

LANDES 2O11, 14

Landes' description is a fitting one for the prophetic excitement that followed the Israeli victory in 1967 in many Evangelical camps. For some, the fact that Israel was now in control over all of Jerusalem signified that "the time of the gentiles" (Lk. 21:24) was over and that the third temple would soon be built in Jerusalem. For many Evangelicals, the Israeli victory also seemed to fit into larger concerns over the experienced erosion of North American culture in the '6os, the war in Vietnam, and the fear engendered by the Cold War (Weber 2004). These concerns were ingeniously given voice in the bestseller The Late Great Planet Earth (1970) which placed them and the Israeli victory in a modified dispensationalist framework and argued that they signaled the beginning of the end times. In the book Lindsey intends to show, and for millions of people he indeed showed, how all the crucial events expected to precede the second coming were taking place around the readers. The success of the Late Great Planet Earth led to an explosion in the prophecy business in the United States; not only numerous books, but also TV shows, videos, and prophecy conferences helped to spread and popularize the identifications between the State of Israel and biblical prophecy (Boyer 1992).

A similar excitement with the Israel victory was also unmistakable among Evangelicals in Jerusalem, and the '7os would see the birth of several Evangelical initiatives and organizations which identified themselves as defenders of the State of Israel and as educators with regards to Israel's role in the prophetic drama. The post-' 67 criticism of the State of Israel that had begun to be heard from the international community and liberal Christians was also important here: for many Evangelicals this clarified that Israel needed not only to be celebrated but also defended ideologically and theologically. One of the most publicized events of the early '7os took place in June 1971 and was called the "Jerusalem Conference on Biblical Prophecy" which attracted at least 1,200 participants from 32 different countries to Jerusalem's convention center in which the gathered Evangelicals were greeted by former Prime Minister David Ben-Gurion (Boyer 1992, 188). The conference hall, according to Weber, was made available free of charge by the Israeli government which had begun to understand the benefits of building a relationship with the Evangelical constituency $(2004,214)$. In fact, as early as shortly after the ' 67 war, Yona Malachy of the Israeli Department of Religious Affairs had 
been sent to the US to study the potential of an alliance with fundamentalist Christians, from which he had returned claiming that American conservative Christians were both very friendly towards Israel, and unafraid of saying so (Weber 2004, 221). ${ }^{8}$ These Israeli initiatives are not reported here to imply that the State of Israel somehow manipulated Evangelicals into supporting it post-' 67 . In fact, the Evangelicals needed little such manipulation since many of them were already convinced of Israel's prophetic role, and from the Israeli perspective such an alliance with the Evangelical constituency made perfect political sense. However, the initiatives are important because they account for some of the sense of appreciation and momentum in the Evangelical scene in Jerusalem in the ' 70 s which was important in the creation of several Christian Zionist organizations. Not only were they living in historical times, they were also recognized by Israeli politicians as having an important role to play in the unfolding of that history.

One of the organizers of the conference in ' 71 was G. Douglas Young who would eventually become one of the most important Evangelicals in the development of the Christian Zionist ministries in Jerusalem (Hanson 2012, Merkley 2001). Young was born in Korea, the son of Canadian Presbyterian missionaries, but later moved to North America for a theological education. After gaining a doctorate in Semitic languages and several academic positions in the US he moved to Israel in order to start the American Institute of Biblical Studies in Jerusalem. ${ }^{9}$ Young identified as a dispensationalist and believed in the periodization of history into specific eras, the future rapture of the believing church, the spiritual restoration of the Jewish people en masse in the (near) eschatological future, and a coming tribulation for unrepentant Jews and Christians (Hanson 2012, 240-246). Throughout the '5os, while still in North America, he had taught that the restoration of the Jews was a fulfillment of prophecy and that Christians should seek closer co-operation with them and reconciliation for centuries of anti-Semitism, as well as theologically re-evaluating their position on Jewish election. Yet Young's version of dispensationalism was also "unorthodox" in that he insisted upon a second rapture of those Jews who accept Jesus as their Messiah-after the rapture of the Church but before the Great Tribulation, an emphasis which was clearly meant to save the Jewish people from the horrible fate projected for them in most dispensationalist narratives (Hanson 2012, 242-243). Furthermore,

8 Malachy's assessment was later published in his American Fundamentalism and Israel (1978).

9 The Israel-American Institute of Biblical Studies was founded in 1957. Later it changed its name to the Institute of Holy Land Studies and later still to Jerusalem University College which is the name it bears today (Merkley 2001, 165). 
according to his biographer, for Young the Jewish people was both distinct from the Church as in classic versions of dispensationalism but also united with the Church in "one family of God" (Hanson 2012, 245). Young, even while he expected a future "spiritual restoration" of the Jewish people post-rapture, also had higher regard for Judaism and for contemporary Jews than most dispensationalists at the time. For Young, the Jewish people was still chosen by God; for Christians not to recognize this unique relationship and how it had manifested in the birth of the State of Israel was not only deeply ungrateful to the Jews for their historical role but also a failure to recognize how God works in history $(2012,245)$.

Although it was generally considered a success, Young was disappointed that the participants at the conference in Jerusalem had not been able to agree on a clear political statement in support of Israel; several participants-among them the chairperson of the conference, Carl F. H. Henry-had been cautious about being interpreted as too "pro-Israel" (Hanson 2012, 233). In consequence Young, and several other likeminded Evangelicals including the influential dispensationalist, John F. Walvoord of the Dallas Theological Seminary, went ahead and published a declaration of their own which emphasized their support for the "unification" of Jerusalem and their resistance to the internationalization of the city that had been a part of the UN partition plan since 1947. A few years later, in 1978, Young organized a second conference, "Congress for the Peace of Jerusalem", and this time he was determined it should be done properly. In preparation for it Young and others published a full-page article in the New York Times which caused considerable controversy. Entitled "Evangelicals' Concern for Israel", it stated:

We believe the rebirth of Israel as a nation and the return of her people to the land is clearly foretold in the Bible and this fulfillment in our time is one of the most momentous events in all human history. While the exact boundaries of the land of promise are open to discussion, we, along with most Evangelicals, understand the Jewish homeland generally to include the territory west of the Jordan River.

YOUNG et. al. quoted in HANSON 2012, 248

In conclusion the statement called upon fellow Evangelicals to recognize this divine mandate and to support Israel in a variety of financial and political ways. Although the second conference drew less attendance from abroad than the first, it was again visited by top Israeli politicians like Jerusalem's mayor, Teddy Kollek, and Israel's newly elected prime minister, Menachem Begin, who was enthusiastically introduced by Young. 


\section{Connecting Israel with the Evangelical World}

The conferences in ' 71 and ' 78 were only two of several initiatives launched by Evangelical Zionists in Jerusalem during the '7os that served to position them as a bridge between Israel and a global Evangelical constituency. For instance, on 2nd February 1978, Douglas Young together with Pastor Claude Duvernoy (French Presbyterian), Pastor Per Faye Hansen (Norwegian), Basil Jacobs (South African), Chuck Smith (US preacher), and several others founded "International Christians for Israel" which was to be a body "to link concerned individuals, churches and organizations, and to coordinate worldwide Christian commitment related to the state and people of Israel". ${ }^{10}$ The initiative was publicly declared in a spectacular fashion at the ancient fortress of Masada by the Dead Sea under the proud rubric, "Masada shall never fall again" (Merkley 2001, 168). Young was elected the new networks chairperson. In '75 a South African branch of Christian Action for Israel was also founded in which Basil Jacobs, Claude Duvernoy, and later also Malcolm Hedding who would become the executive director of the ICEJ, were involved. They were active, like several other similar organizations, through newsletters and expressions of support in Israeli and international media, and would later be involved in the founding of the ICEJ.

While these different initiatives and networks were certainly directed towards fellow Evangelicals in an attempt to win support for the Zionist movement, it is hard to escape the notion that they were also directed at the Israeli political establishment. Interviews with Evangelicals like Young, Duvernoy, and Faye Hansen were frequently published in Israeli newspapers in which the interviewees tried to reduce Israeli concerns that they were missionaries in disguise, and to explain that Evangelicals were staunch supporters of Zionism. A common argument was that there was vast potential, largely untapped by Israeli authorities, in the millions of Evangelicals abroad who supported Israel. It was argued that as Israel after ' 67 was increasingly in need of such international support, aligning with the Evangelicals was simply a matter of political pragmatism. In other words, all through the ' 70 , Evangelical Zionists in Jerusalem worked not only to convince their fellow Evangelicals abroad that supporting Israel was the Christian thing to do, but also the Israelis that working with Evangelicals was the Zionist thing to do. They consciously, simultaneously, and very effectively positioned themselves as the bridge between a large constituency of Evangelical Christians and the Israeli political establishment.

"News release", Central Zionist Archives, $S_{3} 8 \backslash 653^{-t}$, Jerusalem. 
An interesting glimpse into how strategic this ideological positioning was at times is provided in an undated document written by Harold W. Dart, who was the chairman of the International Association of Christians for Israel, and before that involved in the American Christian Committee for Israel. This document, entitled "Christian Attitudes towards Israel: Sectarian and Ideological considerations" - and signed with a "confidential" tag in the top-right cornerwas likely written in the second half of the "7os and addressed to several Jewish Zionist organizations. ${ }^{11}$ The explicit aim of the document was to explain "the most relevant ideological divisions" within Christianity, in order to outline the most effective ways in which to "arouse Christian support for the specific cause of Zionism and Israel". After outlining the groups in typical Evangelical fashion- "non-religious", "liberals", "Evangelicals", and "various sects"12—Dart explains how the first two should be reached mainly by focusing on secular, humanitarian, and historical arguments such as the "democratic aspects of Israel versus the authoritarian and despotic character of its enemies" and "Israel's achievements in restoring the land [and] agricultural development".

The Evangelical group however was different; in addition to humanitarian and historical arguments, advocacy activities here should focus on emphasizing the connections between Zionism and biblical narratives, particularly Bible prophecy. In conclusion, Dart pointed out that although "to date, Jewish Zionist efforts have been directed mainly to reaching the first two elements of the 'Christian World' [nonreligious and liberals] ... the greatest potential ... lies within the Evangelical community". Thus, "specially designed material for use with Evangelicals should be prepared to stress Biblical aspects of Zionism and Christian relationship to Judaism". To anticipate Israeli concerns about evangelization the author also added that "Evangelical tendencies to missionary attitudes can be modified by a proper use of the history of Jewish and Christian relations and examples of Christian tolerance and good will".

Although it is uncertain who the receiver(s) of this strategy document were, and what impact it might have had on Israeli efforts to build Christian

11 "Christian Attitudes towards Israel: Sectarian and Ideological Considerations", Central Zionist Archives, $\mathrm{S}_{3} 8 \backslash 653^{-t}$, Jerusalem. The document is undated but included in a folder entitled "Western European Christian institutions that support Israel. Correspondence, reports, memoranda, surveys, publications, brochures, reprints, newspaper clippings (organized by country)", 1976-1978, so a reasonable guess is that it was written sometime during those years. Furthermore, at least some documents in the same folder were sent to Benjamin Yafa at the World Zionist Organization, Jerusalem, which might indicate the receiver of the document.

12 Literally the document reads (i) "non-religious", (ii) "modernist" or "liberal", (iii) "biblical", "fundamental" or "Evangelical", and (iv) "various sects". 
support for Zionism in the late '7os, it is interesting to note both how pragmatic the author is in assessing the various groups and the various strategies that should be employed to reach them, and how he singles out the Evangelical group as likely to be the most receptive to Zionist ideology. In the late '7os, despite forerunners such as Dr. Young, the alliance between Evangelicals and Israel was still in its infancy and Israeli media constantly misconstrued Evangelical views and activities in Jerusalem. The concern that they had a hidden agenda and were really just interested in winning Jewish souls was ever present, and suspected missionary activities were frequently reported in the press. Dart's document is interesting because it clearly and pragmatically outlines the basis on which the alliance should be built and how Israel could win international Christian support for Zionism. In retrospect, the document sounds almost prophetic in terms of how this alliance would develop, and the basis on which the relationship between Evangelicals and the state of Israel would be structured.

\section{Practical Support and Founding Organizations}

In spite of all these public declarations, budding Evangelical networks, and the attention that they had begun to receive in Israeli and international media, some Evangelical Zionists in Jerusalem started to feel that a more tangible expression of their support was needed. Thus in the '7os, while the prophecy business was booming in the US, Evangelical Zionists in Jerusalem began to organize themselves so as to create the infrastructure for what would become the Christian Zionist ministries in Jerusalem. Many of these organizations were highly dependent on the vision of one charismatic and effective leader, and consequently several of them disappeared or merged with other organizations when the leader no longer had the time or energy to run them. Some, however, would prove more long-lived. The first of the ministries that is still active today is the final brainchild of Douglas Young: Bridges for Peace. In ' 78 , Young handed over responsibility for the Institute of Holy Land studies to another Evangelical Zionist, George Giakumakis, and launched the BFP, an Evangelical organization that was to engage in practical work within Israeli society and in building bridges between Israel and Evangelicals (Hanson 2012, 267). The organization built on the social status and relationships Young had developed in Jerusalem but by this time Young was aged and he never took up the position as director, dying of a heart attack in May 1980. Instead, the position was filled by Clarence Wagner Jr., a graduate from Oral Roberts University who had been running the Spafford Children's Center in Jerusalem for some years. Shortly before he died, Young received the honor, "Worthy of Jerusalem", the city's highest award, from Jerusalem's mayor for his services for the city. 
In '79 another development was also stirring in Jerusalem, centered on the charismatic Dutch Reformed Church pastor, Jan Willem van der Hoeven, who had been the warden of the Garden Tomb in Jerusalem between 1968 and 1975. Van der Hoeven grew up in a Reformed family in Holland, studied theology at the Bible College in London where he also met his Lebanese wife, and was ordained in the Armenian Evangelical Church in Beirut before coming to Jerusalem a year after the Six-Day War. In ' 79 van der Hoeven was involved with several other Evangelicals-Robert Lindsey, the pastor of the Baptist congregation in Jerusalem; David Bivin, another North American Baptist who ran a Hebrew school in Jerusalem; Canadian couple Marvin and Merla Watson; Douglas Young; George Giakumakis; and others-in founding a small prayer community that they called the Almond Tree Branch (Ariel 1997). It was this community that, in '79, launched the first Feast of Tabernacles celebration that has since become the most visible expression of the ICEJ. The rationale for this celebration came from van der Hoeven: according to his reading of Zech. 14:15 gentiles were also commanded to gather in Jerusalem during Sukkoth and it was unscriptural, he argued, that Christians celebrated only two pilgrimage feasts (Easter and Pentecost) while three (including Sukkoth) were actually mentioned in the Bible.

While the feast celebration in ' 79 drew in many Evangelical Christians and further served to consolidate the base of the emerging organization it was 1980 that would mark the real start of the ICEJ when, in July, Knesset passed the Basic Law:Jerusalem, Capital of Israel which provided the impetus. The law did not specify any boundaries, and did not legally change the status of Jerusalem, but it was nevertheless received critically by the international community as a de facto annexation of the larger Jerusalem area, and the UN declared that the law needed to be rescinded. In consequence, as noted above, the few national embassies that had until then remained in Jerusalem were relocated to Tel Aviv.

Among the Evangelicals in Jerusalem, this relocation was met with outrage, and several signed petitions calling on their national governments to rethink their decisions; one of the Evangelicals most involved in these protests was van der Hoeven. When the protests went unheard some of those involved in the Evangelical scene in Jerusalem decided to launch a Christian Embassy to represent the views of "Bible-believing" Christians who were in full support of the Jerusalem law. ${ }^{13}$ The official opening was held in the presence of Mayor

13 Ariel describes the founding of the ICEJ as basically an opportunist move: with the relocation of the embassies the Evangelicals in the group around van der Hoeven had the perfect opportunity to receive the maximum amount of publicity for the new organization. In ICEJ's own accounts, the founding of the organization is rather presented as a 
Kollek during the second Feast of Tabernacles in September '8o. Haaretz reported that van der Hoeven told Kollek that the new organization "expresses the feelings of millions throughout the world who support Israel and who are not obliged to pay lip service to the conventional political pressures of the moment". 14

In terms of positioning themselves as a politically valuable ally to Israel the choice to launch the Embassy, and to frame it as a response to the Jerusalem law was highly effective. The sight of eight hundred Evangelicals marching through the streets of Jerusalem in a show of solidarity was also extensively reported in Israeli newspapers and was likely important in making the Embassy known to the Israeli public. In short, the founding of the ICEJ was spectacular, timely, and very successful. While some media reports seemed uncertain what they should make of these unexpected Evangelical expressions of affection for Israel and the Jewish people, reports were largely positive. Similarly to Dart's letter above, the ICEJ effectively framed themselves as representative of a large Christian constituency that would support Israel's claim to the land, and they would be unmoved - in van der Hoeven's words - by "conventional political pressures of the moment". Their support for Israel was based on the Bible, and neither modern political expediency nor the opinions of national governments or international organizations could trump that.

Although largely similar ideas about Bible prophecy and Jewish restoration were influential in the circles attached to both the BFP and the ICEJ, and even though some of the same people were involved in founding both, their organizational identities were different from the start. Both ministries were interested in supporting Israel through practical means such as investments in the Israeli economy and sponsoring Jewish immigration, and both wanted to be perceived as a "bridge" between Israeli society and the Evangelical world. What made them different was not so much ideology as their views of how they could best fulfill these goals. While the BFP drew upon Young's long and very well-respected engagement with Israeli society, his participation in

spontaneous act of solidarity arising from the outrage they felt when "the nations abandoned" Israel. I think the truth lies somewhere in between; the ideas for an organization had been long in the making but the critical letters sent to politicians in Norway and Holland in response to the decisions to relocate their embassies served to crystallize the new organization's focus and organizational identity. Finally, the public announcement of the organization was perfectly timed and brilliantly executed. It was an opportunity not to be lost.

14 "More than 5,00o now registered for Jerusalem March", Haaretz, September the 23rd 1980, Caspari archives, Media review 80-82. 
Jewish-Christian dialogue, and his interest in Christian education, the ICEJ was much more of a political advocacy organization from the beginning; it was loud, overtly political, confrontational, unashamedly self-confident andat least in theory-much more global. ${ }^{15}$ Furthermore, while the B FP derived most of it support and most of its employees from North America, the ICEJ had its main base of support in Europe (especially northern Europe) and in South Africa. The names chosen for the organizations also speak to these differences; while the BFP saw relationship-building between Christians and Jews as its main occupation - although it always felt that a large part of this relationship derived from its political support for Zionism - the ICEJ was launched as an "embassy" in open confrontation with the international community as expressed in UN resolution 478. The ICEJ were-in an echo of Malachy's assessment of North American fundamentalism noted above-both very supportive of Israel, and distinctively unafraid of saying so.

\section{Navigating the Socio-Political Space}

While the differences between the BFP and the ICEJ during the early years should not be exaggerated - as already mentioned they had similar goals and ideological agendas and they have often cooperated in specific areas throughout their histories-nor should they be completely neglected. As the ICEJ emerged as the figurehead for Evangelical Zionism in Jerusalem during the ' 8 os they also received more coverage in the media, and they became the Evangelical organization that most Christians and Jews, both within and outside Israel, came to identify with Christian Zionism. Consequently, the ICEJ became the organization at the center of much heated debate, and its theo-political agenda was frequently discussed, evaluated, criticized, praised, and misunderstood in the media throughout the ' 8 os and ' 90 s. On the other hand, the differences between the organizations during the ' 8 os also emerge, in no small part, from the characters of the people behind them.

Without doubt, the most important person behind the ICEJ until his resignation in 1998 was van der Hoeven, who was both charismatic and outspoken,

15 In 1981, the ICEJ reported that they had established "consulates" in 16 countries and hoped "to expand by another 10 nations very soon" (Johann Lückhoff, ICEJ Newsletter, 3 oth September 1981). The ICEJ's fast internationalization and establishment of national branches in many countries in the early ' 8 os depended in part on making already existing Evangelical Zionist organizations part of the ICEJ network. Examples of such organizations were: "Help to Israel" (Holland), "Prayer for Israel" (Britain), "Arbeitskreis vur Israel" (West Germany), and "Christian Action for Israel" (South Africa). ("Embassy without a country", David Krivine, Jerusalem Post, June the 24th 1981, Caspari Center, Media Clippings Jan 81-Dec 81). 
but also deeply controversial (Ariel 1997, Merkley 2001). While officially holding the modest title of "spokesperson" of the ICEJ, he was not only the face of the Embassy but also, in Ariel's words, "undeniable leader and chief ideologue" $(1997,373)$. Van der Hoeven was religiously conservative and politically radical, even by contextual standards, and under his leadership the ICEJ ventured into several sensitive political areas-sometimes, I think, more based on the spokesperson's whim than any planned strategy — that made the organization highly controversial in relation to the larger Christian world.

In the early ' 8 os van der Hoeven often expressed hopes for the rebuilding of the temple on the Temple Mount/Haram al-Sharif, and complained of the fact that most Israelis did not care about the issue. ${ }^{16}$ In some cases, he also ventured into relationships with Jewish national religious right-wingers who had similar goals, for instance Stanley Goldfoot's Temple Mount Foundation. In 1984 Meir Kahane, the founder of the ultra-nationalist party Kach, claimed to have been contacted by van der Hoeven but that he had refused to work with him because he was "repulsed" by Christians, and because he considered van der Hoeven a missionary. ${ }^{17}$ In the same year, the ICEJ planned a march to the Temple Mount as part of the Feast of the Tabernacles festivities and, according to Ariel, it was only after the intervention of Mayor Kollek that the leaders of the ICEJ could be convinced to abort it (1997, 384-385). Earlier the same year, the members of the Jewish underground - who had developed plans to blow up the Dome of the Rock on the Temple Mount-had been arrested (Zertal and Eldar 2007, $76 \mathrm{ff}$.), and Kollek was apparently concerned that thousands of Evangelicals on a march to the location might further upset the city's delicate inter-religious balance.

The overtly political, and somewhat excessively self-confident, approach of the ICEJ during its early years is also visible in the naivety with which it engaged with the civil war in Lebanon both before and after the Israeli invasion in June 1982. While a broad majority in the Knesset had voted in favor of the invasion, public opinion in Israel soon became increasingly critical of the war. In contrast to earlier conflicts, it was felt to be a war of aggression that lacked a clear military goal, a sentiment which materialized in a large antiwar demonstration in Tel Aviv in September '82. The ICEJ supported the war effort through opinion pieces, association with the Evangelical pro-Haddad radio station, "Voice of Hope", and even had General Sa'ad Haddad visit the Embassy in the summer of ' 82 , a visit which was described in emotional and

16 "The Temple mount connection", Jerusalem Post, June the 15th 1984, Caspari Center, Media Clippings, Jan 84-Jun 84.

Ibid. 
encouraging terms by the executive director Johann Lückhoff in a newsletter in June. ${ }^{18}$ The people of "Free Lebanon" deserved strong Christian support, he wrote, not only because they were "the last vestige of a Christian nation in the Middle East", but also because they shared a "wonderful, scriptural destiny in common with Israel". 19

As in the question of the expanding settlement enterprise and the interest in rebuilding the temple, the support for Free Lebanon placed the ICEJ ideologically in close proximity to the emerging national-religious camp in Israel. They espoused a vision of Israel that was a mixture of messianic and nationalist sentiments, a religious pioneer state that was an exception in the community of nations and that could only be judged by biblical standards. However, during his time as spokesperson van der Hoeven was not afraid of openly chiding, not only the Christian world but also Israeli society when they failed to live up to his millennial expectations. His outspokenness on such issues is remarkably different from how the ICEJ behaves today. For instance, in 1981, the Jerusalem Post published a four-page article covering the new "embassy" that is telling in this regard. ${ }^{20}$ In the article van der Hoeven tells the author that "we are better Zionists than you Israelis [because] you don't fully believe in your own cause". Israelis, van der Hoeven says, are too compliant with the standards of the modern world when they should be leading it towards the new era; Israel lacks a "sense of mission" and is "assimilating to foreign standards". These comments reflect both van der Hoeven's resistance towards land concessions as part of peace negotiations, and also his critique of the moral and spiritual status of Israeli society. The author of the article makes the remark that van der Hoeven "reproves us [Israelis] like the prophets of old" and quotes the ICEJ spokesperson: "Have you survived the terrible ordeals of your 2,00o year exile, in order to set up at the end an ordinary carnal, self-seeking state like Denmark or Holland or America?" According to van der Hoeven, Israelis are failing to accept their role as the penultimate heroes in the eschatological narrative due to their denial of their religious destiny and their wish to be just like any other people. But Jews are not like other people; it is even "in their blood" to be different, he says, and they need to accept the demands placed upon them by narrative

18 Johann Lückhoff, "Newsletter", June the 7 th 1982, p 1-2.

19 The State of Free Lebanon was the self-proclaimed and internationally unrecognized territory in southern Lebanon that was under the control of Haddad and his allied forces roughly between 1979 until Haddad's death in 1984. For some years it was practically semi-independent but heavily reliant on Israeli logistical and military support. 
and become the light of nations that they are meant to be. If they will only accept their spiritual destiny they will be the heroes of the coming dawn. In response to the author's question about how they then should live in order to fulfill this destiny van der Hoeven responds by quoting Jeremiah (31:31-33) and the conditions of the new covenant, the implications of which are lost on, or at least go unmentioned, by the journalist. For van der Hoeven, of course, this is a reference to the expected spiritual restoration of the Jewish people that will occur when they accept the Messiah. The Messiah is the ultimate answer to their contemporary moral, spiritual, and political shortcomings.

This highlights another point relevant to the ICEJ's negotiation of the social and ideological space in Israel; while the critique of them from Christian quarters outside Israel mainly had to do with their overtly political approach and the way they associated with the national religious right in Israel, the principal question that they had to negotiate within Israel had to do with evangelization. As early as ' 82 , the ICEJ reported that their building had been vandalized by "religious fanatics" who were convinced that "the Embassy is just a front to take away their Jewish identity". ${ }^{21}$ Similar attacks on the buildings and activities of the ICEJ, BFP, CFI, and other Christian organizations in Jerusalem were reported many times in the '8os and '9os and it remains a question of concern for the ministries today. Israeli anti-missionary organizations like the Yad l'Achim (A Hand to Brothers) have specifically targeted the Christian Zionist ministries in Jerusalem and subjected them to a critical examination of their goals. Within Israeli media there has also been an ongoing debate about whether the Evangelicals should be perceived as "true friends" of Israel or rather missionaries in disguise (see also: Shapiro 2011, 2015).

In 1990, however, the ICEJ was also attacked from the other end of the spectrum. In an issue of Mishkan, a Jewish messianic journal associated with the Caspari Center, several of the authors address the ICEJ's outspoken nonmissionary agenda and criticize it on theological grounds. ${ }^{22}$ The ICEJ and the other ministries in Jerusalem have consistently argued that even though they hold to the belief that all peoples_-including Jews—-need to recognize the Messiah, they themselves do not engage in any missionary activities in Israel. To attempt to convert Jews is not part of their mandate as they see it, and it is

21 Johann Lückhoff, Newsletter, March 1982.

22 Mishkan, no. 12, 1990. According to the editorial, the ICEJ was invited, but refused to respond to these critiques in the issue, a refusal which perhaps illustrates the disinclination of the ICEJ to engage in debates concerning evangelization beyond stressing that they are completely uninvolved in such endeavors. 
ultimately unnecessary since the Jews will in any case realize that Jesus is the Messiah at some point in the eschatological future.

Although limited in terms of public impact, the Mishkan issue is important because of what it represents. In the issue, Evangelical and messianic authors who generally saw themselves as part of the Evangelical Zionist movement criticized the ICEJ for its lack of integrity; while they generally recognize the ICEJ's importance, and describe it as a genuine Evangelical organization they also lament its unwillingness to live up to its own Evangelical commitments and, particularly, its alleged silence on behalf of the marginalized Messianic Community in Israel. Considering that the ICEJ, like most Evangelical Zionists, both expects a future "spiritual restoration" of the Jews and perceives this to be the ultimate fulfillment of Jewish identity, an unwillingness to defend and support the Messianic congregations in Israel is too much of a sacrifice in the name of Zionism and social respectability, the authors argue. The ICEJ has gone too far in trying to be acceptable to the Israeli public; in essence, they compromise the Christian message by making Evangelical commitments conditional upon Zionism and Israel. Furthermore, in spite of their claim to represent millions of Israel-loving Christians worldwide, one of the authors claims that the ICEJ is a "self-perpetuating and self-regulating body, independent of any ecclesiastical jurisdiction. It is a voluntary society representing the views of its own limited circle of supporters" (Ross 1990, 15).

In a sense, this absence of broad Evangelical mandate was of course true. The ICEJ was from its inception an Evangelical, non-denominational interest group without any specific ecclesiastical or ecumenical mandate, ${ }^{23}$ despite their own claims - frequently repeated in media and scholarship alike- to represent seventy million Christians worldwide. The political leverage they eventually gained developed gradually, partly through their own work, but also as a consequence of their association with Israeli politicians and civil society. Ultimately, the legitimacy that they gained was the result of self-fulfilling prophecy; if they had not been perceived from the start as representative of a large group of Evangelical Christians they would not have gained as much

23 For instance, the Lausanne Movement for world evangelization has not explicitly addressed the ICEJ, or even Zionism or the State of Israel in any of its formative documents. The only questions relevant here that it has raised concern Jewish evangelization and so-called two-covenant theology in which it simply has affirmed the "orthodox" Evangelical position that all people need to accept Jesus as their Messiah, and that there is no separate path for Jews. See the "Manila Manifesto" and "Cape town commitment" available here: https://www.lausanne.org/category/content (accessed 2019-o6-25). 
attention from Israeli politicians and media. When they gained that attention, however, they also became better known in the Evangelical world.

Yet, in Ariel's assessment of the ICEJ's early years, it is clear that its importance in European and South African Evangelicalism was never equaled in North America where other organizations-among them the B FP - were already established and had a head start (1997). This regional disparity would become even more acute in the fall of 1985 when a controversy arose within the Embassy which ended with the defection of most of its staff and board members from English-speaking countries. ${ }^{24}$ The Jerusalem post reported in October ' 85 that members of the UK branch of the Embassy had resigned and that several Christian Zionists who had long been associated with the Embassy had chosen to boycott the Feast of Tabernacles that year, among them Evangelical celebrities Lance Lambert and Derek Prince. ${ }^{25}$ The reasons for dissent were numerous. According to the defectors there was a general discontent with the "almost unquestioned leadership" of the power duo van der Hoeven/ Lückhoff, their excessive involvement in politics, and their close association with the Likud party. Johann Lückhoff, on the other hand, said that the conflict was caused by the Embassy's decision to stick to its "original goal of comforting Zion" while the dissenters "were more concerned about with reconciling Jews and Arabs". The defections from the board would have consequences: the ICEJ lost some of its credibility in English-speaking countries-something which it later had to work hard to regain-although the most tangible effect of the controversy was that several of the dissenters moved ahead and founded another organization in December '85: the Christian Friends of Israel.

If a concern with the rightist policies of the ICEJ and a wish to work more closely with the Palestinian population were indeed the major reasons for the defection of the British and North American staff, however, there is little evidence for this in the founding stories of the CFI. In concert with the Bridges for Peace and the ICEJ, they identify as Biblical Zionists who understand their main task is one of undoing of the history of Christian anti-Semitism and supporting the Jewish people, materially, financially, morally, and politically. Two of the original founders, both of whom are still the leaders of the organization, were Ray and Sharon Sanders, North Americans who had worked at the ICEJ

24 Ariel attributes the crisis to the "authoritarian" style of leadership within the ICEJ and differences in European and North American political culture (1997), while Merkley does not give any reason (2001). In interviews with me those involved in this crisis have been unwilling to talk about it. 
since June ' 85 , and as volunteers at the Feast of Tabernacles before that. Other founding members were Orde Dobbie-a cousin of British Major-General Orde Wingate, legendary in Christian Zionist circles, who during the British Mandate worked closely with the Jewish Agency and the Haganah-Derek White, and several other North American, British, and French Christian Zionists, most of whom had previously worked at the ICEJ. Theologically educated at a Bible college in Dallas, both the Sanders had been interested in Israel since reading The Late Great Planet Earth in the early '7os, later traveling to Israel in '75. In an interview with me, Sharon expressed a greater identification with dispensationalist narratives than is common at the ICEJ, but she also added that there are parts of dispensationalism "that the Jews are very concerned about" and that those "far-out, doomsday theories" that have been frequent in popular dispensationalism "need to be restudied". In spite of this emphasis on dispensationalism, there is little that distinguishes the CFI from the BFP or the ICEJ ideologically or theologically. They also prefer to see themselves as representatives of a broad Christian "Bible-based" restorationist tradition: friends of Israel who are healing the wounds of the past. Like the BFP however, the CFI has been able to operate with less publicity in the shadow of the larger and more vocal ICEJ.

\section{Covenantal Theology}

In ' 98 , van der Hoeven, the most vocal Evangelical political voice in Jerusalem, had to leave his position as spokesperson for the ICEJ after the board insisted on his resignation (Merkley 2001, 239). ${ }^{26}$ Two years later, the executive director, Johann Lückhoff, who had occupied the central administrative role at the ICEJ, was replaced by another South African, Malcolm Hedding. These changes in personnel were indicative of a change of direction for the Embassy, its theological emphases, and its relationship to Israeli society. As the ICEJ has occupied a central ideological role for the Evangelical Zionist community in Israel since its early years, these changes would also reflect more broadly on the Evangelical scene in Jerusalem and abroad.

Malcolm Hedding is a Pentecostal (Assemblies of God) of British descent who had been active in the Jerusalem scene in the ' 8 os and ' 9 os. He had served as chairman for Christian Action for Israel for close to ten years, been the pastor in the Jerusalem Christian assembly (which later became the King of Kings

26 After his resignation van der Hoeven started a new organization in Israel called the "International Christian Zionist Center" which still remains active to some extent but has never grown into a major Evangelical actor in Israel. 
community) in the late ' 8 os and he had also occupied the position of chaplain at the ICEJ. In the 'gos Hedding returned to South Africa to start a Pentecostal congregation with a specific Messianic orientation in Durban before he came back to the ICEJ to take up the position as executive director in 2000 (Helgesson 2006). ${ }^{27}$ As mentioned in the previous chapter, the Fourth International Congress on Christian Zionism organized by the ICEJ in February 2001 started the shift of emphasis to "Biblical Zionism" instead of "Christian Zionism", one that is, if not a direct consequence, at least in congruence with Hedding's theological emphasis on covenantal promises rather than apocalypticism. In the Biblical Zionism series, a five-volume collection written by Malcolm Hedding and published by the ICEJ in 2004, Hedding specifies what can be seen as the ICEJ's present theological platform.

Christian support for Israel, or Biblical Zionism, is not based on the prophetic portions of the Word of God ... Our support for Israel is based on something far deeper, and that is the promises of the Word of God or the great covenants of history that God made with the people of Israel. The prophetic portions of God's word reinforce these great promises and validate them.

HEDDING 2004, 5, my emphasis

I have italicized the two passages here because they signify how the theological reorientation commenced by the ICEJ in the early 2000 s was (and still is) understood by its leadership. The biblical foundation for Zionism lies in God's promises to the Jewish people, and apocalyptic passages are understood as secondary, yet important validations of these promises. While emphasis on

27 To date, no scholarly work to my knowledge has analyzed the profound influence of South African Christianity on the development of the ICEJ and on Evangelical Zionism in Jerusalem more broadly. This influence is visible both in the many prominent South African Evangelicals in Jerusalem and in the theological development that followed. Furthermore, during the ' 7 os and ' 8 os, it was common among South African Evangelical Zionists to compare their own situation with Israel and to identify with the Israeli struggle. For instance, in a newsletter written in 1977, Basil Jacobs, the then secretary of Christian Action for Israel, writes that "South Africa and Israel are riding out a stormit may in the end turn out to be the same one". Robert O. Smith has emphasized how North American Christian Zionism developed in close relationship with North American national identity (2013), and a similar argument has been developed by Timo R. Stewart in the Finnish context (2015). Considering the Israeli and South African contexts in the '70s-'8os, and the close relationship between those two states during the apartheid era (Polakow-Suransky 2010), it is not unreasonable to expect a similar dynamic as the one described by Smith and Stewart at play also among South African Christians. 
the biblical covenants had of course been an important part of Evangelical Zionist and restorationist theology long before the early 20oos, Hedding placed these covenants at the heart of his theology. For him, and consequently for the ICEJ, covenantal theology was understood as a more solid, more biblical, and notably less controversial way to express and motivate Evangelical forms of Zionism. While prophetic speculation had been the primary mode of motivating such support following the Six-Day War, it had also framed Christian Zionists as excessively interested in the apocalypse, the horrors of the coming tribulation, and the identification of contemporary geopolitical actors with the eschatological drama. By focusing instead on the covenants such negative side effects could, at least in theory, be avoided. It is important to note, however, that the emphasis on covenantal theology is not less eschatological than theologies built upon "the prophetic portions" of the Bible; in Hedding's work, the covenants are always placed in an explicitly eschatological framework. The purposes of the covenants, and the ongoing restoration of the Jewish people, are nothing less than the ultimate redemption of the world.

Israel is the vehicle of world redemption; therefore, to curse her or hate her or despise her is to resist the purpose of God-eternal salvationflowing to the world through her ... Her position before God is special because she plays out a role historically that is unique to her ... If the nation of Israel fails, then God's plan for world redemption fails. She is the vehicle of world redemption.

HEDDING 2004, 8-928

Traditionally, covenantal theology draws upon reformed Christian thought, and argues that God interacts with the world through the institution of various covenants: with Abraham, Moses, David, and in the New Testament. Covenantal theology has often been criticized by dispensationalists as a form of "replacement theology" due to its traditional ways of conceptualizing the relationship between the Old Covenant (with biblical Israel) and the New Covenant (with the Church). In the aforementioned Swords into Ploughshares however, David Parsons explicitly contrasts the "covenantal theology" of the ICEJ with both premillennial dispensationalism and replacement theology, both of which are deemed unbiblical (Parsons 2013, 16).

28 "Israel" here has a multi-layered meaning in a way that is typical of Evangelical Zionist thought; it refers most directly to the people (or nation) of Israel, but by typology also to the contemporary state which is understood as a natural and unambiguous extension of biblical Israel. 
In the ICEJ's understanding of covenantal theology, the "Abrahamic covenant" naturally plays a pivotal role. There are two aspects of this covenant that are important here: in it a specific people is chosen to be the vessel of God's redemptive plans, and they are, eternally and irrevocably, promised a specific piece of land. ${ }^{29}$ The current physical restoration of the Jewish people to the land that they were promised in the Abrahamic covenant will be followed by a spiritual restoration in which the Jewish people accepts the Messiah (Hedding 2004, Parsons 2013). This spiritual restoration, Parsons argues, is neither conditioned upon a future tribulation (as in many dispensationalist narratives), nor should the believing Church expect a rapture preceding it. These formulations significantly de-stabilize the boundary—which in dispensationalist narratives is often very strict-between the present and the future millennial era. While theoretically still separated, the physical restoration to the land is already the beginning of the millennial era and the eschatological end game. This vision is framed more as an ongoing eschatological process than a chart in which all the details can be filled in and precisely timed.

Another significant effect of placing emphasis on the enduring covenants instead of Christian apocalypticism is that it draws the ICEJ's Zionism considerably closer to Jewish religious Zionist thought. It cuts away some of the superfluous religious (and specifically "Christian") material that is alien to Jewish messianic thought and frames the redemptive process more in line with those espoused by the national religious camp (Ravitsky 1996). Faydra L. Shapiro has identified Jewish religious Zionists as the most "natural partners" to Evangelical Zionists because they share "a fervent religious faith based in the Hebrew Bible, conservative social values, and an ardent, faith-based Zionism" (2015, 108-109). Shapiro also points out that for many Jewish and Christian Zionists alike, "this movement of Gentiles embracing the Jews and helping them, in the service of God, is nothing less than another example of prophecy in action" $(2015,114)$. Although Christian Zionists were developing relationships to the religious settler movement in the early ' 8 os, the covenantal theology being developed by the ICEJ was making its theology and eschatological vision less foreign and presumably more acceptable to Israelis with a religious-nationalist vision of Israel.

29 Parsons applies a juridical language to account for the difference between ownership of the land which is irrevocable and right of residence which is conditioned upon the Jewish people's obedience and spiritual status. In other words, exile and the diasporization "does not impair their underlying [land] title before God. It merely reflects their breach of the conditions for residency" (Parsons 2013, 22). 


\section{Going Mainstream}

While the Evangelical Zionists in Jerusalem during the '7os and ' 8 os were actively trying to shape Israeli policies on questions such as the protection of Christian communities and Holy places, the freedom to change religion, abortion, and land concessions, the Evangelical Zionist ministries today are generally more cautious about criticizing Israeli internal politics or presenting their own political visions. Previously, there had been a sense of impatience in the Christian Zionist scene in Jerusalem, a sense that in spite of the prophetically significant events of ' 67 , the Jerusalem law, and the steady flow of new Jewish immigrants, the Israelis still refused to fully embrace their prophetic destiny. This is visible, for instance, in van der Hoeven's open criticism of the Israelis and their resistance to surrendering to the demands of eschatological narrative. It is also visible in the ' 90 os when several of the ministries were frequently-and openly_critical of the Oslo accords and the Camp David summit. The failure of the latter, for instance, was welcomed by the ICEJ director, Johann Lückhoff, in a Jerusalem Post article. ${ }^{30}$ While territorial concessions - particularly those concerning Jerusalem - as expressed in the land-for-peace formula are still resisted by most Evangelical Zionists in Jerusalem, it is far less common to hear these critiques today. ${ }^{31}$

Currently, among the ministries as well as among the volunteers in Jerusalem, there is a very different sense of patience and eschatological moderation; they now seem much more content to wait for events to unfold in their own time. There are, I suspect, several reasons for this shift in attitude. First to be considered are the processes of accommodating to Israeli society and gaining social legitimacy that I have been tracing in the previous pages. There has been a learning curve to understanding how to express their views and how to work in and with Israeli society in ways that are both communally accepted and effective locally. Second, this accommodation was also made easier by broader political shifts within Israeli society in the 2ooos that have brought the Evangelicals more into the Israeli mainstream politically. Following the failure of the Oslo process in the mid-' 9 os, the Camp David summit in 200o, and the outbreak of the Second Intifada the same year, Israeli politics have been moving steadily to the right under

$30 \quad$ "Radical Christians sigh with relief over failed peace talks", Tamar Hausman, Haaretz English edition, July the 28th 200o, Caspari Center, Media Clippings Jul oo-Sept oo.

31 See for instance Johann Lückhoff's comments to Yitzhak Rabin when the latter visited the Feast of Tabernacles in 1994: "Premier preaches peace to visiting Christians", Haim Shapiro, Jerusalem Post, September the 21st 1994, Caspari Center, Media Clippings Aug 94-Jul 95. 
three consecutive Kadima/Likud governments headed by Ariel Sharon, Ehud Olmert, and Benjamin Netanyahu respectively. Some of the positions held on the issues of the Palestinians and the peace process that were previously mostly found in the nationalist right now increasingly occupy the political center. Although the ministries have historically worked with both leftist and rightist governments in Israel, the right has always been a more natural ally due to the organizations' resistance towards the land-for-peace formula and the two-state solution. This implies that for the Evangelical Zionist ministries things have simply moved in the right general direction during the 200os: the peace process, although periodically revived, is in hibernation and there are no credible options on the table for changing the status quo. While there is often a sense of alarm in the newsletters and other publications of the ministries concerning Islamist violence, outbreaks of European anti-Semitism, or criticism of Israel from the international community, the general sense is that none of these are "existential threats" in the same way as a peace process involving Israel giving up land. To be clear here, the ministries do not in theory resist a genuine peace process, but they do not perceive any peace which is based on the establishment of an independent Palestinian state as viable. To the extent that this position, which the organizations have defended more or less since they were founded, has become more common among the Israeli public, so also has the ideological distance between them been reduced.

At the same time, the ministries in Jerusalem have for more than thirty years now worked hard to show that they are indeed Israel's best friends by investing millions of (US) dollars in Israeli society. ${ }^{32}$ These funds have been injected into a variety of different programs: support for new immigrants, elderly care for holocaust survivors, schools and educational programs, orphanages, food banks, bomb shelters in Sderot near Gaza, the repair of homes, and tourism, as well as sponsoring more than 100,00o Jewish immigrants. ${ }^{33}$ These initiatives

32 David Parsons reported in an interview with me that their "injection into the Israeli economy", including the Feast of Tabernacles, is between $\$ \mathrm{US}_{2} \mathrm{O}-25$ million annually. I have not, however, seen any official financial reports so I have not been able to confirm these figures nor examine how they have changed historically.

33 This is by a conservative count. The ICEJ reports that they have sponsored 117,000 immigrations, and spent roughly \$US45 million since 1989 (see http://int.icej.org/ news/special-reports/icej-aliyah, accessed 2019-06-25). The BFP and CIF have been less directly involved in sponsoring and coordinating immigration but have worked with new immigrants, and assisted them on arrival. Most of such work has been channeled through the Jewish Agency. 
have consistently been presented as "unconditional" acts of solidarity with the Jewish people, as attempts to try to repair the damage done by Christian anti-Semitism, and as acts of love for Israel. Through them, hundreds of thousands of Israelis have gotten in contact with the ministries either directly or indirectly, and many have come to know them as Evangelical friends of Israel. Stories about contact with Israeli Jews, and opportunities to explain "why they do what they do" in Israel frequently occur and are particularly treasured among the volunteers. In many programs, however, funding from the ministries is channeled through Jewish governmental and non-governmental agencies. Cheryl Hauer, at the BFP, explains:

Often Jewish organizations will come to us because they've heard of us from other Jewish organizations. We give a large portion of our food every month to soup kitchens and those kinds of organizations here in Israel. And also, you know, we do the direct distribution, but we have eighteen communities that we are very strongly connected to and we take truckloads of food to those communities every month. And we give it to the municipality and then the municipality in turn distributes it to the neediest of the needy. The only thing that we ask in all of these circumstances is that people that are distributing the food make sure that the end recipient knows that that food came from Christians, because that's what we're all about. ... And so the bags that we deliver the food in have a message on the outside of the bag that says in Hebrew, that says this food is coming to you as a gift from Christians around the world who stand in support with the nation of Israel.

In other words, in the 2010 s the ministries have become deeply financially embedded in Israeli society, probably to an extent not recognized by most Israelis.

Faydra L. Shapiro has argued that Israeli responses to the Evangelical Zionist organizations, while diverse, have often been guided by a pragmatic approach: "We need all the friends we can get" (Shapiro 2015, 100). While for many orthodox Jews Christian donations are a religious question, ${ }^{34}$ most Israeli Jews on the liberal end

34 Shapiro argues that, for Orthodox Jews, the relationship to the Evangelical organizations and Christian donations is largely a halachic matter. Many rabbinical organizations have prohibited the acceptance of Christian donations, but that has not stopped numerous religious organizations, families, and individuals receiving such support. The ministries sometimes admit to difficulties when working within the ultra-orthodox community, but all of them also testify that they frequently do so. 
of the religious spectrum view the Evangelicals primarily through the lens of politics. What matters to them is the ministries' Zionism, not their conservative Christianity which is mostly treated as a "(hopelessly) harmless quirk" (2015, 104). In my reading of the representation of the ministries in Israeli media, this pragmatic approach has been dominant since the beginning, although criticized from time to time either from a religious perspective (emphasizing the risk to Jewish religious identity), or from a leftist one (emphasizing the rightist views of the ministries and their potentially toxic mixture of politics and religion). ${ }^{35}$

If offering social aid to Israeli society is a major part of the activities of the Evangelical Zionist ministries, another is what in Israel is called hasbara (public diplomacy). And just as the aid aspect of the ministries has become increasingly embedded in Israeli society, so has their advocacy. For the ministries, hasbara most directly translates as defending Israel politically and theologically, particularly vis à vis the Christian world. As noted above, this is an activity in which the ministries have been involved since the ' 8 os via newsletters, media reviews, publications, and speaking tours, but it was further developed during the first part of the 2000 s as a result of the organizations' being among the founding members of two new, and largely independent, institutions: the "Knesset Christian Allies Caucus (KCAC)" and the "European Coalition for Israel" (ECI). The former was founded in 2004 on the initiative of Josh Reinstein and Yisrael Beiteinu MK Yuri Stern in order to function as a bridge between the Knesset and Christian supporters of the State of Israel. ${ }^{36}$ Its work is mainly directed towards the Christian

35 A more in-depth analysis of Jewish Israeli perceptions of Christians is provided by Jackie Feldman in his recent ethnography of Jewish tour-guide performances (Feldman 2016). In Feldman's account, Jewish guides often exhibit an ambiguous attraction/repulsion relationship with Christianity which is at least partly rooted in their own religious identities and the historical relationship between Christians and Jews. While the guides are often fascinated by Christianity, and might also be drawn to it, or "seduced" $(2016,117)$, they are also disgusted and often employ different strategies to maintain the borders between themselves and the pilgrims; these often occur in practices outside of the pilgrims' view that Feldman calls "prophylactic rites" (2016, 131) such as (ritually) purifying themselves after spending a week with the pilgrims, or by throwing away personal greetings that they have received together with the tip at the end of the tour. Although explicitly limited to tour guides, who have much more extensive experience of Christians than most other Israelis, Feldman's account also demonstrates some of the complexities and ambivalences that might be hidden under the surface of "the pragmatic approach" in the Jewish Christian encounter.

36 "Rising star", The Jerusalem Report, November the $7^{\text {th }}$ 2013. The work of the Caucus has expanded and now there are 25 Caucuses globally which are organized under the umbrella organization "Israel Allies Foundation". 
world but also tries to achieve more positive Israeli attitudes towards Christian supporters of Israel, both in Jerusalem and globally. For the organizations in Jerusalem, it has also been helpful in decreasing bureaucratic difficulties for the ministries: by softening visa restrictions for volunteers which allows them to stay for longer terms, for instance. The ECI was also founded in 2004 by the three ministries-together with Netherlandsbased "Christians for Israel-International" — to work as a pro-Israel lobby directed at the European Union. In contrast to its founding organizations, however, the ECI operates on a largely secular platform, and references to Bible prophecy or interpretations of the Scripture are entirely absent from its explicit lists of aims and motivations. Instead it focuses on the history of anti-Semitism in Europe, a shared Judeo-Christian tradition, and argues for Israel primarily on ethical and juridical grounds. These rhetorical differences have made the organization much more able to operate in relation to the European Union than if it had been explicitly associated with Christian Zionism. ${ }^{37}$

\section{The Ministries Today}

In the 20oos, then, Evangelical Zionism in Jerusalem, although still strange and alien to many Israelis (Feldman 2016), seems to have become increasingly mainstream and socially accepted. One the one hand the ministries exist in an environmental bubble, a specific Evangelical sub-culture in a Jewish majority context while, on the other, they are also deeply embedded financially, socially, and politically in Israel.

While the political beliefs of the ministries have remained remarkably stable throughout their histories - accentuating, as it were, Jewish territorial control over the geographical areas captured in 1967-their ways of articulating those beliefs and their public images have undergone some quite significant changes. Most notably, the ICEJ made an effort, particularly in the 199os, to whittle away superfluous religious and political content that was controversial within Israeli society, and outside it, among Christian communities. These changes were largely driven, not by a reassessment of core religious and political beliefs, but rather by social demands; the main engine behind them was a willingness to be perceived as true friends of Israel, without a hidden apocalyptic agenda, and thus facilitate smoother

37 The ECI homepage does not include any references to the founding organizations, but they are available in the pamphlet "European Funding of Palestinian Institutions: Issue Brief" printed by the European Coalition for Israel, unpublished. 
co-operation. Post-20oo, as their political beliefs have found more resonance within Israeli political culture, the ministries have also become increasingly embedded in Israeli public diplomacy efforts. Their position as bridge to a large Christian constituency situates them as a highly valuable diplomatic tool for hasbara. ${ }^{38}$

However, the process of accommodation that I have traced here should not be understood as in any sense complete or finalized. Throughout its history Evangelical Zionism has participated in, and negotiated, two specific discursive arenas: one in Israeli society and the other in the Christian world; these processes of negotiation continue to be highly salient today. In reference to the former, Evangelical Zionism - and the ministries as embodiments of this phenomenon-exists on the border of Israeli discourses and has often tried to find expressions and articulations of its identity that are acceptable to that society. Its adherents know they are different, and they know that, as Christians, they come to Israel with particular historical baggage that forces them to work hard to convince Israelis that they are friends through thick and thin, without any hidden motives. As to the latter, Evangelical Zionism perceives itself as a reform movement engaged in re-evaluating "traditional" Christian positions towards the Jews (see Chapter Five). The ministries have never been as representative within Christianity as they have claimed to be, yet during the past fifteen years they have achieved a strong momentum, in particular by focusing more on charismatic forms of Christianity in the Global South. Charismatic Christians in Latin America, in Africa south of the Sahara, and in East Asia are paying increasing attention to Israel, and the ministries in Jerusalem — particularly the ICEJ — have long since realized the potential of this trend.

An interesting picture of this new global Evangelical climate is presented in the Global Survey of Evangelical Protestant Leaders (2011) conducted by the Pew research forum among participants at the Lausanne Conference in Cape Town. When asked about their opinions of different religious groups-both Christian and non-Christian-seventy-five percent of the interviewed Evangelical leaders report that they have a generally favorable view of Jews. All other religious groups-not counting other Christian groups - are recorded as being viewed unfavorably. Seventy-three percent of the interviewed Evangelicals also believe that God's covenant with the Jewish people continues today (22\% do not). With regards the State of Israel, forty-eight percent of the interviewees

38 Josh Reinstein in "Rising star", The Jerusalem Report, November the 7 th 2013. 
say they believe that Israel is a "fulfillment of Biblical prophecy" ( $42 \%$ do not agree). However, the most interesting results of the survey are visible only when these numbers are compared to the geographical origin of the participants. In general, Evangelicals among leaders from the Global South are more conservative on moral and political issues than leaders from the Global North, and more likely to claim to read the Bible literally and to profess belief in the rapture. Southern leaders are also more likely to sympathize with Israel than are their counterparts in the north. For instance, fifty percent of sub-Saharan leaders sympathize more with Israel than with the Palestinians, a figure which should be compared to the thirty percent of US leaders who choose this option. When it comes to the question most closely related to Christian Zionism-whether or not the participants believe that the state of Israel is a fulfillment of Biblical prophecy-participants from the Global South are also more likely to say that they do.

This trend in the global Christian climate towards an increasing identification with the state of Israel among charismatic and Evangelical Christians in the Global South is very relevant for the ministries in Jerusalem who have always striven to represent global "Bible-believing" Christianity vis à vis Israel. All three organizations are also highly aware of these developments and work to make the most of them. For instance, David Parsons at the ICEJ observes:

Our new areas of growth are in Latin America, Africa and Asia and the potential ... We go to Brazil and there is a stadium filled with 120,000 people waving Brazilian and Israeli flags. And we go to Africa and there's 10,00o pastors gathered to pray for Israel. And, you know, we're engaging with our Chinese Christian leaders, [and] their church networks number in the tens of millions and God is speaking to them to get involved with Israel. And to me it's a move of the Holy Spirit. It is pure motives; it's upright motives. You can't impugn it. It's just a work of God.

The movement of the Holy Spirit that influences charismatic Christians to identify with Israel is part of the eschatological vision. It too is a sign of the times. While the organizations-particularly the ICEJ — have always claimed to represent a large group of Evangelical Christians, it is primarily during the last fifteen years that circumstances have changed to the degree that, for the first time, they have the real potential to develop into the global organizations that they have always desired to be. 
TABLE 1: Percentage of Evangelical Protestant leaders, by region, who believe that the state of Israel is a fulfillment of Biblical prophecy:a

\begin{tabular}{llll}
\hline & Yes, true & No, not true & No response \\
\hline All leaders & 48 & 42 & 10 \\
Sub-Saharan Africa & 58 & $3^{2}$ & 10 \\
Asia Pacific & 53 & 40 & 7 \\
South/Central America & 49 & 43 & 8 \\
US & 44 & 48 & 8 \\
North America & 43 & 49 & 8 \\
Middle East-North Africa & 40 & 51 & 9 \\
Europe & 38 & 49 & 13 \\
\hline
\end{tabular}

a Pew Research Center (2011), “Global Survey of Evangelical Protestant Leaders”, p. 65.39

\section{At the Embassy 2012}

Arriving at the ICEJ's mansion on Rachel Imeinu Street for the first time, I am aware of their history—although not to the extent that I am now-and I am aware of their somewhat ambiguous and unstable social position within Israeli society. Considering this history and the ways in which ideological parameters often structure social encounters in Israel (Markowitz 2013a), I am also very uncertain about how I will be received at the Embassy and whether, and to what extent, they will allow me to carry out my research among them. Today, I have been invited to the ICEJ by one of the volunteers whom I met through a mutual acquaintance, and he has promised to show me around the facilities and introduce me to the people working there. More or less as soon as I arrive, however, I am called up to the office of the media director, David Parsons. In the two-hour-long meeting with him, I am thoroughly questioned: not only, or even primarily, about my planned research project, but more about how I position myself religiously and politically in relation to Israel.

I recount the content of this meeting here since I believe it illustrates how the contextual circumstances that I have outlined in this chapter structure

39 In the full report, available on the website, not all these numbers are included. I am grateful to the Pew Research Forum for sending me a more substantial regional breakdown of the answers to Q 35 . 
both the discourses of the organizations and the volunteers, and also my encounters with them and the ways in which I have tried to navigate this discursive terrain. Many ethnographers studying Evangelicalism recount similar situations with their interlocutors where their own religious identity is called into question, and various approaches have been developed in order to deal with this situation. These range from that of the detached observer, to more participatory approaches, and even to critical engagement with one's own religious identity as a valid and important subject position (Bielo 2009, 32-33, Howell 2007).

In my encounter with David Parsons, the more detached stance is never an option simply because he does not accept it as a viable subject position. During the conversation I naturally explain my research design, but what is of primary importance to him, and therefore fundamental to deciding whether he will let me carry out the research is, rather: (i) my personal relationship to born again Christianity; and, (ii) my political position vis à vis Israel and the conflict. He asks me about my religious background in Sweden, the denomination to which I belong, how it stands with regards to Israel, and if I am "born again". He asks me how I view different aspects of the Israeli context and the "situation", and how I view the ICEJ and the work that they are doing. He also questions me about my thoughts on "Christian Zionism" and several different authors - particularly Victoria Clark, Stephen Sizer, Stephen Spector, Donald Wagner, Timothy Weber, and Paul Merkley whose works are in the book shelf behind him-who have written about Christian Zionism and the Embassy before me. In a way, I am being asked to develop a life story that will plausibly explain to him what I am doing in Israel, what my motives are, and why I am interested in my chosen subjects. While never unfriendly, his manner throughout the discussion is definitely probing, with a critical air to it.

I try to be as honest as possible in response, explaining my interest in Christian Zionism in similar terms to those presented in the previous chapter. Yet, considering the politics of language, and how easy it is in this particular context to be placed somewhere along the political continuum, I am also careful with what I say, using terminology which does not situate me as a critic. This negotiation with David exemplifies how the strict separation that researchers often attempt to construct between their personal and professional capacities -insider/outsider, participant/observer, political and religious views - can be impossible to uphold. In this case it breaks down primarily because David Parsons does not accept this as a viable division, and he is probably right. What we think, personally, has huge impact on the research that we design and conduct, not least in a conflicted area of research such as this one. Ultimately — and admittedly somewhat to my surprise-I pass 
the test and am rewarded with a "reluctant yes" to conducting research at the Embassy. The main reasons for this are probably that I am deemed sufficiently an insider (religiously and politically), and because I describe how I want my research to be different from some of the previous work that David feels has not represented the ICEJ and their views honestly. Having received that "reluctant yes" from David Parsons the doors to the Bridges for Peace and the Christian Friends of Israel are also opened. In that sense, he has functioned as a gatekeeper for me. In general, the other two organizations are less reluctant than the ICEJ to co-operate in my research, maybe partly because the ICEJ has already agreed to do so, thereby, in a certain sense, "vouching" for me. When we leave the room, the volunteer who has followed me there tells me that I should feel proud; according to him, I am the first researcher ever to get this opportunity.

To some extent negotiations between me and the organizations continued throughout fieldwork but, in general, restrictions relaxed the more comfortable they became with my presence amongst them. Both in relation to the organizations and to the volunteers, however, I continued to occupy something of an in-between position: moving between insider and outsider, believer and non-believer, participant and observer (Tweed 2002). My positioning was not only my doing, but also depended on the particular volunteers whom I was interviewing, how well they knew me, and how they understood where I was coming from. While some volunteers addressed me as they would any insider, some were more cautious and "diplomatic" in their responses and narratives; yet others could become quite polemical, framing the interview situation more or less as an argument with me, or with an internalized audience of Christian critics or the international community. Often, towards the end of the interviews, I was asked about my own ideas of Israel, about how I understood the "restoration", the political climate, the various parties, or how it all related to Christian salvation history.

The chapters that follow explore the volunteers' narratives about themselves in relation to Israel. I have suggested in this chapter that these narratives need to be understood in relation to the organizations' historical development and the tensions in which they exist in relation to Israeli society as well as larger Christian discourses, tensions that have structured their development and which continue to do so in the present. At the same time, however, the individual stories are obviously also expressions of personal beliefs, problems, desires, experiences, and longings. The next chapter focuses on a few of these individual biographies and the agencies and circumstances that have brought the volunteers to Israel. 